International Journal of Linguistics, Literature and Culture
Available online at https://sloap.org/journals/index.php/ijllc/
Vol. 7, No. 2, March 2021, pages: 57-69
ISSN: 2455-8028
https://doi.org/10.21744/ijllc.v7n2.1142

\title{
Stylistic hallmarks of Obama's (2009) and Al-Maliki's (2006) Inaugural Addresses
}

Moayad Mohammad Hassan a Abbas Lutfi Hussein b

\section{Article history:}

Submitted: 09 November 2020

Revised: 18 December 2020

Accepted: 27 January 2021

\section{Keywords:}

Al-Maliki's (2006);

Obama's (2009);

stylistic;

\begin{abstract}
In inaugural addresses, presidents (e.g. Obama and Al-Maliki) intend to convey their intentions and plans and to announce their new political strategies to convince the public to accept and support them. To attain such purposes, they have often recourse to the shrewd selection of linguistic elements and manipulation of rhetorical devices. Thus, this paper aims to investigate the stylistic hallmarks utilized in Obama's and Al-Maliki's Inaugural Addresses, focusing on the roles realized by these hallmarks in delivering the intended messages. Obama's (2009) and Al-Maliki's (2006) Inaugural Addresses have been selected to be the data of the study. For the data analysis, a qualitative method involving the identification of the most prominent stylistic features is followed. The paper concludes that both Obama and Al-Maliki resort to different stylistic features and devices with relatively different degrees. This slight diversity of this use seems to be due to the nature of the two languages and to the different goals sought by the two speakers. Moreover, metaphor, repetition, parallelism, and metonymy are the more dominant devices in Obama's Address than in Al-Malik's. A simile is only observed in Obama's address. Owing to the nature of their authority and responsibility, both Obama and Al-Maliki somehow use the same syntactic strategies to provoke the listeners' zeal using different tools such as religious, social, and historical citations to stir up their people.
\end{abstract}

International journal of linguistics, literature and culture (C) 2021.

This is an open access article under the CC BY-NC-ND license (https://creativecommons.org/licenses/by-nc-nd/4.0/).

Corresponding author:

Moayad Mohammad Hassan,

The Sunni Endowment Divan Religious, Teaching and Islamic Studies Directorate, Iraq.

Email address: moayad.hassan55@gmail.com

\footnotetext{
a The Sunni Endowment Divan Religious, Teaching and Islamic Studies Directorate, Iraq

${ }^{\mathrm{b}}$ Mustansiriyah University, College of Arts, Baghdad, Iraq
} 


\section{Introduction}

It is commonly conceived that language and politics are interconnected and intimately linked at a fundamental level as that language is how politics is expressed. Or as Chilton (2004) puts it, language is "how politics or political discourse and ideas are widely disseminated". In this vein, Harris (1979) contends that "in politics, words have a powerful effect" and "language is how political ideas are transmitted to the community." One of these political ideas that are given skillfully through the use of language is the inauguration.

The inauguration is a "ceremony introducing someone into a new position", particularly the President. Although this term is mostly connected with presidents, it can apply to "any kind of official first". More elaborately, Collins Concise English Dictionary (2016), defines the inaugural address as a "speech given during a formal ceremony or speech event by which the speaker informs the people of his or her intentions as a leader".

In the inauguration speech, every president starts with a speech including phrases and sentences designed to be memorable, i.e. he/she refers to communal values drawn from the past. Moreover, he/she, in this kind of speech, implicitly or explicitly, announces his new political strategies and policies that are to be administrated in his presidential agenda. Inaugural addresses are well prepared "to appeal to their countrymen to take pride in their country, to cherish their long-held traditions, and to put behind them the divisiveness of the past campaign and unite for the common good" (Rohler \& Cook, 2001). The inaugural address, as the official entrance of the president, would be employed to declare political values and persuade the public to accept and support them. Therefore, the appropriate use of stylistic and rhetorical strategies seems to be a prerequisite for the president to convince the audience with his/her successful administration later (Wagner et al., 2015).

Politicians pay a lot of attention to various stylistic techniques to enhance their ideas and to glorify their public image. They apply these stylistic traits in their speeches to strengthen their thoughts and opinions and to create an impression of being authoritative leaders and thus, to persuade their people (Cappetta et al., 2006). Thus, the upcoming pages are devoted to the definition of stylistics focusing on its main components to elicit a proposed model for the stylistic analysis of Obama's and Al-Maliki's Inaugural Addresses.

\section{Stylistics in General}

Various views by various scholars and linguists have been formulated to account for what stylistics means and what it involves. Yet, no one definition can be nominated as comprehensive and all-inclusive. Traditionally, stylistics is taken to be the study of the linguistic items in actual language use. Following the fact that all texts have style, Childs $\&$ Fowler (2006) state that "a style is a manner of expression, describable in linguistic terms, justifiable and valuable in respect of non-linguistic factors". In the same vein, from a linguistic point of view, Leech \& Short (2007), define stylistics as the linguistic "study of style" which is viewed as an exercise in describing what use is made of in language. Textually, stylistics is the study of oral and written texts. It is the description of the linguistic characteristics of all situationally restricted uses of language. Relationally, Mugair (2014), maintains that stylistics focuses on texts and gives much attention to the devices, parts of speech, and figures of speech. It goes further to look into "the effects of the use of the devices on the reader".

Briefly, stylistics is considered as the modern version of the ancient discipline known as "rhetoric" which taught language users how to structure the argument, how to make effective use of figures of speech, and how to create a speech in a way that can have an absolute influence on listeners or readers.

علم " Likewise, Arabic stylistics is described by Arab scholars as a sub-branch of rhetoric known as ilm alma'ani الهعاني". Arabic rhetoric is a "pragmatic analysis that is concerned with the grammatical, semantic, pragmatic deviation and linguistic structuring". Arabic rhetoricians investigated the elements of effective discourses and agreed that rhetoric can be defined as "the process of delivering what is inside the rhetorician to the audience influentially" (Abdul-Raof, 2006: xiii). Three components of rhetoric were recognized: (علم الدمعاني) (the science of meaning), (علم البيان) (the science of eloquent speech) and (علم البديع) (the science of affective speech). The first science is concerned with the successful delivery of meaning in its abstract sense. The second one focuses on the correct choice of lexis to unambiguously formulate the intended meaning. The last one deals with the ways of embroidering speech through the use of figures of speech and poetic devices (الهاثمي), 2001:4).

Terminologically, (البلاغة) is used to refer to 'rhetoric' in Arabic which means "the successful getting at the intended meaning". In its linguistic use, or as (ibid: 32) designates it, and it is defined as: مطابقة الكلام لما يقتضيه حال المخاطب

[Matching the speech with the requirements of the context of the situation of the addressee] 
However, English or Arabic politicians have their ways of using language to present and convey their ideologies and thoughts. In this way, stylistics is seen as how the politician employs "language, his choices of words, arrangements, and form of sentences" to express his/her philosophies and governmental plans (Raffique \& Saddique, 2014).

\section{Stylistic Devices}

Stylistic devices are the instruments manipulated to strengthen images, help to realize ideas, and emphasize certain issues. In other words, they are literary techniques used to heighten the effectiveness of expression. Importantly, these techniques employed in political discourses and texts are determined by the conditions of communication. For example, politicians often use irony when they want to create a contrast or discrepancy between what is said and what is meant, or in certain humorous situations, to criticize the out-party politely. Further, rhetorical questions are very frequent to inspire the audience to contemplate important issues. Repetition also plays a role in conveying the politician's message, simply because "repeating a word or phrase in different parts of the speech helps the audience make connections as if you were sewing your speech elements together with a thread" (Dlugan, 2008).

Metaphors, personification, simile, and epithet also contribute to the effect of an utterance. They are stylistic devices that can augment the speakers' influence. Essentially, they are initiated to embellish what is being said. Metaphors, personification, and simile together with connected concepts such as symbolism and analogies are often the core of speeches as an effective means of communication. Metaphors are often utilized by politicians to make an impression on their audience by expressing ideas in some way extraordinary.

Using stylistic devices in the speech, a politician can enhance the arguments of the text, i.e. utterances became more vivid, organized, and structured. This idea is affirmed by Simpson (2004) who states that "to do stylistics is to explore language, and, more specifically, to explore creativity in language use". Accordingly, the essence of conducting stylistic study lies in the fact that the various forms, patterns, and levels that constitute linguistic structure are an important index of the functions of the text.

For Fahnestock (2011), stylistics is based on "the rhetorical tradition also adds to the vocabulary of language analysis". Accordingly, "the richest source of descriptive concepts comes from the figures of speech". What's more, stylistic devices are traditionally employed to reflect an aesthetic function of language. Commonly, the main function of these devices is to intensify the speaker's utterance and to make the political speech more figured and emotional.

In Arabic literature, stylistic devices are also enriched in language use. Stylistic devices such as alliteration, rhyme, consonance, assonance, and onomatopoeia are made use of when a sound and an intended sense usually have a sort of relationship as they are clear in most of the commonly used (Jabur, 2007). He (ibid) points out the interaction of different types of lexical meaning, such as metaphor, simile, irony, epithet, metonymy, pun, oxymoron, etc.; they are all used as semantic stylistic devices. For example, unlike simile (التشبيه), the semantic stylistic device of metaphor (الاستعارة) is used to exhibit an implicit comparison between two different things

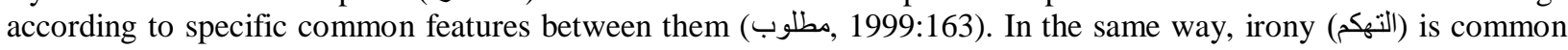
in political discourse, particularly, when there is a reference to "dignity in the position of insult, tidings in the position of warning, the excuse in the position of blame, praise in the place of sarcastic, etc." (ibid:375).

The deviation of the patterns of syntactic structure is used as a stylistic device where abnormal or unexpected patterning of the linguistic units appear either to patterns of the syntactic arrangement or to the completeness of sentence structure (Jabur, 2007). Standard Arabic performs certain inverted occasions on which certain grammatical elements are reversed due to some syntactic restrictions (الصاحبي, 1997:189). As a stylistic-syntactic device, parallelism is accomplished when a similar syntactic structure is repeatedly used in adjacent phrases, clauses, sentences, or paragraphs. Al-Ameedi and Al-Ameedi \& Al-A'ssam (2018), point out that parallel structure has a role in increasing the persuasion of the text, conveying and brilliantly reinforcing the message. In particular, in Arabic, parallelism is related to rhymed prose as it gives the structure a musical impact.

In line with English, the Arabic corresponding term of repetition is either (التكرير) or (التكرار), both of which designate hyperbole and multiplication (السجلماسي 1980:476). Arabic also makes use of antithesis when using counter-proposition to signify a straight contrast to the original proposition. The use of rhetorical questions as a figure of speech is modeled for its persuasive impact without the anticipation of an answer as this question tends to encourage the listener to reason what the reply to the question must be.

Hassan, M. M., \& Hussein, A. L. (2021). Stylistic hallmarks of Obama's (2009) and Al-Maliki's (2006) inaugural addresses. International Journal of Linguistics, Literature and Culture, 7(2), 57-69. 


\section{Methodology}

The method followed in this research is a qualitative descriptive method involving the identification of the stylistic features and devices in the texts to detect the functions behind their use in both Inaugural Addresses of Obama (2009) and Al-Maliki (2006). The first inauguration of Barack Obama as the 44th President of the United States took place on Tuesday, January 20, 2009. The inauguration, which set a record attendance for any event held in Washington, D.C., marked the instigation of the first four-year term of Barack Obama as President. In his speeches to the audience, Obama referred to ideals expressed by Lincoln about renewal, continuity, and national unity. Obama mentioned these ideals in his speech to stress the need for shared sacrifice and a new sense of responsibility to answer America's challenges at home and abroad.

On the other hand, the Iraqi Prime Minister Address, on July 26, 2006, through which Iraqi Prime Minister AlMaliki spoke to a joint meeting of Congress in the chamber of the U.S. House of Representatives. In his remarks, he talked about security in Baghdad and other parts of the country, his decision to ban the operation of militia forces, and efforts to combat terrorism in the region. He also appealed for more reconstruction aid and talked about U.S. and Iraqi interests in the future of Iraq (Wikipedia, 2016).

The selected data have been analyzed in terms of the stylistic features that these two inaugural addresses display. In other words, the stylistic analysis is carried out on the basis of four main levels: firstly, thematic features that are related to the structural behaviour of the speech given in front of audience in terms of the precedence of narrating the events according to their importance and of sequences of telling the aimed speech in story- like method, secondly, sociocultural features that are involved in religion, society and cultures touching peoples' patriotic spirit and recalling to their minds religious, sensitive, historical events and famous guided leaders, thirdly, syntactic features through which language users employ different word orders and syntactic structures to the benefit of exhibiting stylistic features to deliver functions concerning their intended massages; finally, the rhetorical features as metaphor, repetition, simile, metonymy and parallelism, that have been used so as to express ideas and opinions in a more vivid and visual way, are also of the interest of this study .

\section{Data Analysis}

In general, the language used in political inaugural addresses exhibits certain peculiar features that make it distinctive from other varieties of language use. Although some features share with everyday situations, they remain exclusive with politicians. The following are the main stylistic features employed by Obama and Al-Maliki in their Inaugural Addresses of 2009 and 2006 respectively.

\subsection{Thematic Features}

Features related to the thematic scheme focus on the structural behavior of the speech given before the audience. Skillful speeches produced either orally or written have certain arrangements in terms of the precedence of narrating the events according to their importance and sequences of telling the aimed speech in story- like method.

\subsubsection{The Theme}

In contemporary literary studies, a theme is a central topic for which a text is built up. Themes can be divided into two categories: a work's thematic concept is what readers/listeners "think the work is about" and its thematic statement being "what the work says about the subject" (Leech, 1981).

In this respect, the theme of Obama's inaugural speech revolves around his instance of stressing the kind of life expected for the Americans and longing towards finding a better life either explicitly or implicitly; this idea is repeated in his address. This life can be obtained through following ancestors' examples with their old historical values to overcome the challenges Americans face.

"The time has come to reaffirm our enduring spirit; to choose our better history; to carry forward that precious gift, that noble idea, passed on from generation to generation..."

Looking closely into the Arabic data, although the topics of the Arabic inaugural address are variant concentrating on issues related to the new Iraq as it were, the addresser (Al-Maliki) stirs up the most current situation in Iraq namely the remarkable transfer from dictatorship to democracy era, as explicitly expressed in the opening of his inauguration: 
"انه لمن دواعي سروري ان اكون /ول رئبس وزراء عر/قي منتخب دستوريا حيث نذوض معركتنا من اجل الدفاع عن ديوقراطيتنا الناشئة وشعبنا الذي ولئي

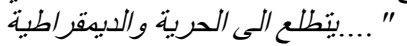

[It is my pleasure to be the first constitutionally elected Iraqi Prime Minister where we are fighting for our democracy and for our people, who are looking for freedom and democracy.]

He also tackles the issue of terrorism describing it as an epidemic that has been defeated with the help of Americans. " أشكركم على تصديمكم المستصر على مساعتنا في الحرب ضد وباء الارهاب"

[Thank you for your continued determination to help us fight the epidemic of termism.]

\subsubsection{Plot Structure}

Literarily speaking, the plot is a term used to designate the events (which should be narrated in a sequence) that make up a story or the main part of it. Stylistically, a careful examination of Obama's inaugural speech reveals that he develops six elements to make up the structure of his speech. He starts his speech with opening keys when he initially expresses his humble thankfulness to the American people for giving him this honorable task and to the expresident Bush for his service to the USA. He also shows a great amount of gratitude for the sacrifices of his ancestors. Since the economic crises have been the preoccupation of most Americans and being wise enough, Obama then admits these dilemmas frankly raising the issues and giving, at the same time, a promise to meet all these challenges with his powerful administration "But know this, America - they will be met".

Suspecting Americans' capability to overcome crises and after acknowledging the crises, Obama thirdly resorts to his optimistic tone saying that Americans are capable of overcoming the challenges reminding his people of the struggles of the past citing the scripture and the Independence Declaration, "America is still there". Beseeching cooperation from the opposing sarcastic politicians was the fourth part of his speech, and addressing them in this sensitive statement "their memories are short", to gain their approval for the sake of the nation. Afterward, speaking on behalf of the world, he maps a new foreign policy that is tied to common, human ideals repositioning of America's global involvement. Finally, Obama lays responsibility not only on the armed forces but also on the ordinary citizens in terms of the spirit of service that will govern the success of his government.

A careful examination of the Arabic speech, also demonstrates that the topics of the inaugural address are offered according to a specific order. This order reflects Al- Maliki's awareness of the necessities and priorities of the Iraqi people. He initially expresses his great gratitude to the attendance naming them as the representatives and to all American people whose support has helped Iraq in its critical days.

$$
\text { "دعوني ابذأ بشكر الشعب الامريكي باسدي وباسم الشعب العر اقي من خلالكم على دعمه لشعبنا" }
$$

[Let me begin by thanking the American people in my name and the name of the Iraqi people through you for their support of our people.]

Then, Al-Maliki starts displaying the priorities giving more emphasis to the crucial ones including: the war against terrorism as the most important demand Iraq and international communities are urgently looking for.

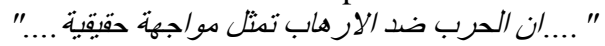

[The war against terrorism is a real confrontation]

The concept of gained democracy has its priority in Al-Maliki's statements when he sets it after getting rid of terrorism as an outcome of all sacrifices given by all Iraqi people through decades.

\section{[We are building a new Iraq on a democratic basis]}

$$
\text { "......نحن نبني عراقا جديدا على اساس دبيقراطي }
$$

Al-Maliki afterward talks about a new policy the new Iraq wants to follow represented by mending the damage caused by the policies of the former regime especially on relations with neighbors"

$$
\text { [Our relations with our neighbors] [علاقاتنا مع جير/ننا.... " }
$$

Being the first parliamentary elections under a permanent constitution, Al-Maliki shows this progress as the core from which a newly elected government has been appointed. This is Al-Maliki's other priority.

[The first parliamentary elections]

$$
\text { "... اول انتخابات برلمانية" }
$$

Hassan, M. M., \& Hussein, A. L. (2021). Stylistic hallmarks of Obama's (2009) and Al-Maliki's (2006) inaugural addresses. International Journal of Linguistics, Literature and Culture, 7(2), 57-69. 
Al-Maliki then gives sufficient illustration for economy clarifying its importance as one of the essential topics he cackles in his word. He illustrates some examples in this respect saying that the market is showing signs of social prosperity, where many people can buy materials they couldn't buy in the past.

[Iraqi economy will continue to grow steadily]

$$
\text { " ان الاقتصاد العر/قي سيبتصر بالنمو" }
$$

The speaker also emphasizes respecting human rights and adds that the topic of freedom and human rights prescribed by the ex- regime and its policy and its mass graves have gone.

[We must respect human rights]

$$
\text { " احترام حقوق الانسان" }
$$

The existence of armed militias is another topic that has been stressed by the speaker promising to resolve all militias without exception. This insistence to deconstruct the militias come after the semi-civil war was about to break up in Iraq then.

\section{[Dissolution of all militias]}

$$
\text { " حل كل المبليثبات" }
$$

Finally, reconstruction and unemployment are the last topics that have been raised in Al-Maliki's address. He demonstrates the role of the state to solve these problems.

\section{[Reconstruction projects in these areas will tackle the problem of unemployment]}

$$
\text { "مشاريع اعادة الاعمار في تلك المناطق ستعالج مشكلة البطالة" }
$$

\subsection{Socio-Cultural Features}

Features involved in society and cultures are also interesting for those who want to stir up their audience when addressing them, touching their patriotic spirit and recalling to their minds sensitive, historical events and magnificent past of the great leaders as shown in the following features.

\subsubsection{Religious Connotation}

Connotations contribute to the overall discourse meaning of a text. They strengthen "the rhetorical force and the traditional significance of political speeches" (Borowska, 2014), (particularly, inaugural addresses). Through mentioning the name of God or the Scripture, Obama resorts to religious connotation to reveal power or devotion to God. His speech is determined by the idea that Americans are a nation selected and blessed by God. Consider the following examples:

- God's grace upon us.

- God bless the United States of America.

-We remain a young nation, but in the words of Scripture, the time has come to set aside childish things.

The reason behind Obama's recourse to citing reference to God and The Bible is to give spiritual credence, support, and authority to his speech as he thinks that the majority of Americans are very religious.

On the other side, the Arabic address also contains several divine citations which are made use of by Al-Maliki to send specific messages. He resorts to the divine qualities to both expose Islamic values and principles in which human freedom and its rights are fundamental and to reveal the real face of terrorist factions whose claim, falsely, is to apply Islamic laws. In this respect, he cites some verses from the Glorious Quran to support his religion's appeal. The extract below illustrates the citation from the Glorious Quran as Allah Almighty says:

$$
\text { "من قتل نفس بغير نفس او فساد في الارض فكأنما قتل الناس جميعا" }
$$

\section{[Whoever kills a soul without a crime or corruption in the earth as if he killed all people]}

\subsubsection{Historical Past}

Another stylistic contrivance used by Obama is concerned with his appeal to the historical past of the American people.

For us, they packed up their few worldly possessions and traveled across oceans in search of a new life. For us, they toiled in sweatshops and settled the West; endured the lash of the whip, and plowed the hard earth. For us, they fought and died, in places like Concord and Gettysburg: Normandy and Khe Sahn. 
By recalling the four epic battles (Concord, Gettysburg, Normandy, and Khe Sahn) for American freedom, Obama beckons Americans to find courage for the days and battles ahead. This would give support, consolidation, and weight to his assertion.

Since the main concern of Al-Maliki's address is the concept of democracy that is fought by ex-regime and terrorism, he tries to recall to the minds of the attendance and all the world the disappointment that befell Iraqis when they found themselves alone to fight the opposition of the ex-regime in 1991.

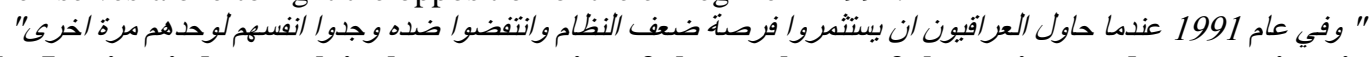

[In 1991, when the Iraqis tried to exploit the opportunity of the weakness of the regime and rose against it, they found themselves alone again.]

\subsection{Syntactic Features}

The diversity of English sentence structures is to the benefit of language users to employ different functions among which is to exhibit stylistic features. Thus, speakers (particularly politicians) make use of different sentence types and pronouns (the two most prominent syntactic features utilized in Inaugural Addresses) to deliver their intended messages.

\subsubsection{Sentences}

To elaborate on his ideas, Obama relies most frequently on the use of clauses joined by coordinating conjunctions. The use of compound sentences has come as a compromise between complex sentences that may cause some kind of hardness or weakness in a speech and simple sentences that are easy be trapped to be boring. To avoid both cases, Obama resorts to coordinating conjunction and linking clauses and /or phrases along his speech resulting in compound sentences and/ or phrases that ease his loaded thoughts. Here are some examples manipulated by Obama:

"For us, they packed their worldly possessions and traveled across oceans in a search of a new life". "For the world has changed, and we must change with it". ".. let us brave once more the icy currents, and endure what storms may come"....

Relatively less used compared with compound sentences, Obama resorts to complex sentences manifested by the use of relative clauses to elaborate on his thoughts and express his ideas more vividly.

"... each day brings further evidence that the ways we use energy strengthen our adversaries and threaten our planet".

"... we can meet those new threats that demand even greater effort-even greater cooperation and understanding between nations".

It seems that Obama is rarely inclined to simple sentences particularly when he wants to sum up his statement, focusing on a specific point, giving a conclusion because short, simple sentences can create tension, haste, or urgency. For the Arabic data, the three sentence types are manipulated; a few simple sentences are used because the political discourse is usually being addressed to tackle vital issues that need more elaborations to deal with. Thus, complexity is used to serve the function of delivering the demanded messages. To illustrate, Al-Maliki employs complexity in his address to elaborate on the ideas he aims to set up in front of his audience who are selective political members. The following sentence, for instance, makes a good illustration to the use of complex sentence whose purpose is to add some kind of identification upon the demonstrative ولئك [those] using the relative pronoun أنين [who] which clarifies the referent.

$$
\text { "ان الحرب ضد الار هاب تمثل مو/جهة حقبقية مع اولثك الذبن بريبون اطفاء شعلة الحرية" }
$$

[The war against terrorism represents a real confrontation with those who want to extinguish the torch of freedom.]

Syntactically, though most sentences are declarative; imperative and interrogative sentences have also been noticed in Obama's inaugural speech. Declarative is mostly initiated to convey facts and display statement. Imperative sentences, carrying the sense of directness and power, are made use of to make requests or call for action; interrogative ones always make people think and listen carefully to the speaker.

"Let us brave once more the icy currents, and endure what storms may come."

" who suggests that our system cannot tolerate too many big plans."

Hassan, M. M., \& Hussein, A. L. (2021). Stylistic hallmarks of Obama's (2009) and Al-Maliki's (2006) inaugural addresses. International Journal of Linguistics, Literature and Culture, 7(2), 57-69.

https://doi.org/10.21744/ijllc.v7n2.1142 
In the same vein, Arabic data represented by Al-Maliki address has also a tendency towards the use of imperative. Imperatives are used to express requests and to give orders, commands, and instructions. Imperatives usually express an intention to influence the listeners' behavior (Imperatives, 2009). Strikingly important, no interrogative sentences have been recorded in Arabic data.

\subsubsection{Pronouns}

[Let me speak clearly]

$$
\text { " دعونسي اتحدث بكل وضوح" }
$$

Pronouns (such as we, us, our, you, I, and they) are chiefly manipulated in Obama's Inaugural Address. For example, with the use of 'we', ' us ' and 'our', Obama attempts to unconsciously or subconsciously create identification with his audience. He intends to get himself closer to his audience, making them have more sympathy with him, and to tell them (Obama and his audience) to belong to the same class and share common interests which are essential to shorten the distance between him and the audience. Implicitly, this use of these pronouns can help minimize the group difference.

-We the People have remained faithful to the ideals of our forbearers, and true to our founding documents.

-For us, they toiled in sweatshops and settled the West; endured the lash of the whip, and plowed the hard earth.

Yet, in certain cases, Obama resorts to the pronoun ' $I$ ' when he directly expresses himself to his audience.

- "I thank President Bush for his service to our nation."

- "Today I say to you that the challenges we face are real."

Obama utilizes the pronoun 'you' to directly address his opponents. By using 'you', he wants to show a kind of challenge to his enemies and to reveal the distance between him and his opponents. He uses it to refer to people other than Americans.

- "We say to you now that our spirit is stronger and cannot be broken; you cannot outlast us, and we will defeat you.

'They' generally has a function of grouping up people and uniting them as a whole. Obama particularly employs the pronoun 'they' to refer to (i) things (challenges America faces) (ii) past heroes and honorable people who sacrificed themselves to establish freedom and welfare in America and (iii) America's opponents and enemies.

- They are serious and they are many. They will not be met easily or in a short span of time. But know this, America: they will be met.

- They have something to tell us today, just as the fallen heroes who lie in Arlington whisper through the ages. We honor them not only because they are guardians of our liberty....

- For they have forgotten what this country has already done; what free men and women can achieve when imagination is joined to common purpose, and the necessity to courage.

The exploitation of Arabic pronouns also does its bit to denote certain cases. It is obvious that Al-Maliki strictly uses the first singular pronoun $\boldsymbol{I}$ and its paradigm referring to himself alone putting himself the official speaker on behalf

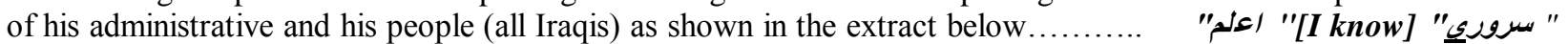
[my pleasure]" دعونيـ"[let me].

The first plural pronoun and its paradigm (we/ our / us) is also manifested, relatively more than singular one, in Al- Maliki's address. The manifestation of the pronoun in question reveals the fact that the speaker, this time, tries to attribute his people with whatever he refers to or talks about involving them together and giving the impression that he and his people are embodied in one entity. The following extract support that claim: "نخوض [.... "معركتنا" [we fight our battle....]

The use of the second pronoun $y \boldsymbol{o u}$, and its derivations, undoubtedly, appear extensively to refer once to all audience who represent the American congress and to all American people other times. "...... [Thank you for your determination...].

Almost the same tendency of using pronouns is embodied in both languages. The third plural pronoun and its derivations (they/ their/ them) are not exceptional. They are used to designate Americans' and Iraqis' enemies who are sometimes referred to using their nouns as criminals, terrorists, etc. 
[The terrorists themselves appear and reveal...]

\subsubsection{Modality}

Another characterization the address is marked by is the use of modal verbs must, will, and can. Modals show how a man of principle, Obama, accepts no compromise concerning his beliefs in the matter of better change for his states. Obama's utilization of modality, particularly the modal verb "will" in his speeches mostly reveals the fact that how confident the speaker can be in the eventual success of the exchange through taking decisions utilized by this model. The modal verb "must" designates obligation; its occurrence with the first plural pronoun "we" signals both the speaker's authority and listeners' urgencies to act together with him. The following extract shows this use of modality:

-"We will build the roads and bridges...."

-"We must pick ourselves up...."

Though modality exists in both languages, it is realized differently. However, in both English and Arabic, it refers to the speaker's attitude towards the assessment of /or judgment of what he/ she says. Through modality, the Arabic speaker (Al- Maliki) expresses his subjective attitudes towards the events that have happened in Iraq and their factuality status. In his use of the extract below, the speaker, by using the Arabic modal يجب , expresses both obligation and necessity.

\subsection{Lexical Features}

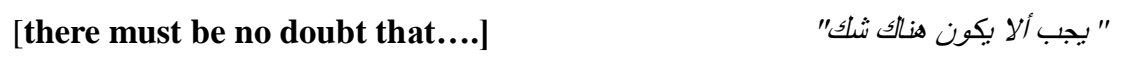

The employment of specific lexical items can have magical effects on their receivers. As it is known, politicians beneficially play with their words artfully to convey their messages in a way that the use of words appears to be selectively made. Noun phrases manipulated in the speech are inclined to simplicity with the trend of being formal, though somewhere colloquial. Their occurrences show deliberateness in listing things following the priorities beginning with the economy, medical care, energy, education, and ending with a strong national defense. Giving reference to patriotism, Obama retrieves the word America and the collective noun USA to attract his audience's attention towards the unity and togetherness of the American people.

Obama intensively uses abstract nouns, particularly when referring to divert aspects. For instance, when he wants to increase the perception of Americans' supremacy over others, he employs words such as greatness, as in "the greatness of our nation", and journey in "the course of American history as a journey". Moral qualities are dealt with by Obama when referring to abstract nouns such as honesty, virtue, and so on as illustrated "With hope and virtue, let us brave once... " and "we gather because we have chosen hope over fear... ".

In the same vein, Obama tends to use words in full form rather than words in shortened or abbreviated form, as this can strengthen the effect of the message he wants to convey. Consider the bold-typed words in the following examples:

- "These are the indicators of crisis."

-" They will not be met easily or in a short span of time."

- "So let us mark this day with remembrance."

The 'buzz words' such as America' and 'Americans' 'peace', 'hero', 'unity', 'believe' have a great share in Obama's address. Mastuo (2002 cited in Ito, 2012) argues that the frequencies of these words are due to the senses that they convey; they are mostly manipulated to arouse U.S. citizens' patriotism. For any politician to make his speech more comprehensible, he must choose "words that are unique to a group or individual and that have specific rhetorical power ... by using preferred words a speaker can establish the right to address the audience" (Hart, 1997).

In common with English data, the Arabic address also reveals a heavy use of nouns. Compared with concrete nouns, the majority of nouns are abstract. The high amount of abstract nouns reflects the supreme abstract goal of the speaker while seeking freedom, human rights, and other abstract notions. In this regard, Al-Maliki, through exhibiting new Iraq with its new prosperities, repeatedly uses the abstract nouns of freedom, democracy, etc. to reveal the prominent achievements that Iraq has obtained by all Iraqis' sacrifices. To illustrate, the following extract shows the use referred to:

"حيث نخوض معركتا من اجل الدفاع عن ديمقراطيتا الناشئة وشعنا الذي بتطلع الى الحرية واللديقراطية وحقوق الانسان وحكم القانون"

Hassan, M. M., \& Hussein, A. L. (2021). Stylistic hallmarks of Obama's (2009) and Al-Maliki's (2006) inaugural addresses. International Journal of Linguistics, Literature and Culture, 7(2), 57-69.

https://doi.org/10.21744/ijllc.v7n2.1142 
[Where we are fighting to defend our emerging democracy and our people, who aspire to freedom, democracy, human rights, and the rule of law]

\subsection{Pragmatic Features}

It seems that Obama's address is characterized by the excessive use of assertive ( in comparison with other illocutionary acts) by which he avows to the people that he insists on attaining his governmental agendas and plans, "Each time we gather to inaugurate a President we bear witness to the enduring strength of our Constitution". Relationally, the illocutionary act of commissive verbs that lay the responsibility upon the speaker through giving his addressee the sense of commitment appears in Obama's address. This use has come to calm Americans down that all obstacles will be overcome through his optimistic willpower articulated in the illocutionary act of commissives: "But know this, America - they will be met".

Other illocutionary acts of verbs have been used directly to inspire his audience to increase their self-confidence to figure their future: "... we must pick ourselves up, dust ourselves up, and begin again the work of remaking America".

\subsection{Rhetorical Devices}

Obama uses various types of rhetorical devices particularly repetition, simile, metaphor, metonymy, and synecdoche to persuasively deliver his messages that are abstract with those whose lexical presentation gives visual aid to be understandable.

\subsubsection{Repetition}

Repetition is often defined as the deliberate use of the same thing over and over again for emphasis. Repetition of a particular word, phrase, or idea helps the listener to better understand and memorize the word, phrase, or idea. Repetition is one of the most preferable stylistic figures in political speeches. Politicians repeat the same words several times so that the concepts or ideas will be better comprehended and memorized by their audience. Consider:

- "The time has come to set aside childish things. The time has come to reaffirm our enduring spirit."

- "In reaffirming the greatness of our nation, we understand that greatness is never a given."

- "Our challenges may be new. The instruments with which we meet them may be new."

It is clear from the examples uttered by Obama that the function of repetition is to show emphasis and strengthens the impression produced on the addressee. The restatement of an idea at intervals not only promotes clarity but also encourages its acceptance. Moreover, repetition can help Obama tie the theme together and this would create clarity for his audience. Being used in political inaugural addresses, repetition not only makes it easy for the audience to follow what the speaker is saying but also gives a robust musical quality to the speech and makes it more striking.

Having a persuasive and emotional impact on the audience, Arabic rhetoric also shows great interest in terms of using repetition. This interest is employed in Al-Maliki's address repeatedly. For instance, the following word and their derivations are used to highlight the importance of the election.

$$
\text { "اول رئيس وزراء عر/قي منتخب دستوريا ... الدمثلون الدنتخبون" }
$$

[Iraq's first constitutionally elected prime minister ... elected representatives]

Throughout repeating such words, people understand the importance of the repeated words and making it easy to memorize the intended words as well.

\subsubsection{Metaphor}

One of the important stylistic tools of political persuasion is a metaphor. Metaphor gives a direct representation of a subject or object. Lakoff and Johnson (2008: 04) confirm that "metaphor is pervasive in every life, not just in language but in thought and action. Our ordinary conceptual system, in terms of which we both think and act, is fundamentally metaphorical in nature". It gives freshness and vivacity to words and expressions deployed in the address. It is a stylistic device in which two things are compared because they have something in common although 
they are different in all other respects; it is a condensed simile used to make the description more vivid and more striking.

Apparently, through the use of metaphor, Obama introduces himself as a strong leader who is responsible for his country. So, he masterly uses metaphorical phrases to gain people's attention towards a certain idea (Staugaite, 2014: 30). In his Inaugural Address, Obama uses the word 'heart' metaphorically to arouse people's emotions. Poetically, the 'heart' is known to be the organ of human emotion. Owing to this, Obama resorts to metaphorical language to focus on the preservation of peace in the world.

-"That's where peace begins -- not just in the plans of leaders, but in the hearts of people."

- "We carry all that history in our hearts."

Here, the use of the metaphorical word 'heart' would support Obama's wish that people all around the world live peacefully and secure liberty across the globe. In other words, he wants to say that the values of freedom, heritage, and principles depend on people's internal values.

Correspondingly, Mio (2005) argues "speeches that contain more metaphors may be perceived to be more inspiring because they can stir up emotional connections with the topic or with the speakers while also conveying the message of action". Relatedly, metaphors help the audience catch the connection between what people know and the new information, and look at the familiar things the other way round. Put simply, they give a possibility to interpret the new information and to come to a certain conclusion (Sheveleva, 2012).

In the same vein, the Arabic address reveals many situations of metaphorical utilizations that give various pictorial and influential images. Throughout his presentation, Al-Maliki describes the obtained freedom as if it has a taste that Iraqis have recently liked and they are not ready to give it up as shown in the following extract:

[Today Iraqis have tasted the taste of freedom] " لقد ذاق العراقيون اليوم طعم الحرية "

\subsubsection{Parallelism}

Parallelism is concerned with a similarity in the syntactic structure of a set of words in successive phrases, clauses, sentences; successive words, phrases, clauses with the same or very similar grammatical structure. It often occurs with the public address to indicate giving two or more parts of the sentences a similar form to give the whole a definite pattern. In his Inaugural Address, Obama uses parallelism to add balance, rhythm, and clarity to the sentence, to impart grace and power to their messages, and to emphasize a contrast by balancing some words or parts of speech against each other:

- "We will build our defenses beyond challenge, lest weakness invites challenge. We will confront weapons of mass destruction so that a new is spared new horrors. We find the fullness of life not only in options but in commitments. And we find that children and community are the commitments that set us free."

It is clear from the above extract that parallelism is a product of "balanced arrangement achieved through repetition of the same syntactic form" (The Oxford Dictionary of Literary Terms, 2008 s.v. 'parallelism').

The phenomenon of parallelism is also manifested through the Arabic data though relatively less than English. AlMaliki makes use of this stylistic device to connect the phrases below together:

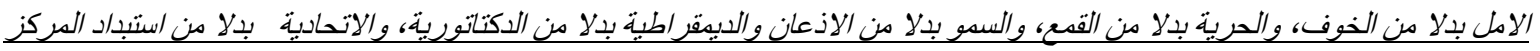
[Hope instead of fear, freedom instead of repression, and supremacy instead of acquiescence and democracy rather than dictatorship, and federal rather than the despotism of the center]

\subsubsection{Metonymy}

Metonymy is used to link an object or concept to an object or concept that is related in a way or another. This figurative use of language is always attributed to developing symbolism; it also contributes to more profound meanings to common concepts and objects. This kind of figurative use of language is used as alternatives for the real mean things (Perrine, 1988: 571): "What the cynics fail to understand is that the ground has shifted beneath them ..." (= the opposing stale politicians). "... we remember .... those brave Americans ..." (= the Americans in service). Further, being eloquent, Obama has employed metonymy in his inaugural address when employing the part for the

Hassan, M. M., \& Hussein, A. L. (2021). Stylistic hallmarks of Obama's (2009) and Al-Maliki's (2006) inaugural addresses. International Journal of Linguistics, Literature and Culture, 7(2), 57-69.

https://doi.org/10.21744/ijllc.v7n2.1142 
whole (Perrine, 1988: 571). Obama has nominated the name of places to designate wars in: "For us, they fought and died, in places like Concord and Gettysburg; Normandy ...".

In his speech, Al-Maliki also resorts to the stylistic tool of metonymy when he wants to refer to the new ear Iraq is witnessing, after a period of torture and wars. In the following extract, he portraits the ex-regime and its policy when depicting its consequences:

[We have moved from mass graves, torture rooms, and chemical weapons...]

" لقد انتقلنا من الدقابر الجماعية وغرف التعذيب والاسلحة الكيمباوية"

\subsubsection{Simile}

The comparison of one thing with another of a different kind is used to make a description more emphatic or vivid (e.g. as brave as a lion). This figurative use of language is meant to compare those in service as "the fallen heroes" using the word "just as" to foreground the meaning of what they have in common in terms of the spirit of service.

"They have something to tell us today, just as the fallen heroes who lie in Arlington whisper through the ages". Interestingly, no Arabic use of simile is detected by Al-Maliki's address.

\section{Conclusions}

The stylistic analysis reveals that Obama and Al-Maliki, resort to different stylistic devices with relatively different degrees. The diversity of this use seems to be due to the nature of the two languages and to the different goals aimed to get by the two speakers. Nevertheless, the following are the most prominent findings arrived at:

1) Thematically, the two speeches represent two different main themes related to the concerns of the two speakers and their priorities to exhibit them.

2) Structurally, it is obvious that both speeches are well designed in terms of their plot structures with a salient difference by which Arabic speech has more planned topics to display before the audience than English one.

3) Though in different degrees, keen use of religious citation appears in both speeches. Obama resorts to Biblical citations to God to give spiritual credence and authority to his address. Al-Maliki also uses aayas from the Glorious Quran to support his demand for freedom and the right of living and to expose the truth of terrorism.

4) Unlike Arabic data, the most important rhetorical- stylistic device used in English speech is a metaphor. It seems that the Arabic speaker is so inclined to be more direct than the English one. Yet, they both resort to the most prominent stylistic devices; namely repetition and parallelism, metonymy, and simile. By repeating the same words several times, a concept or idea will be better understood and remembered by the audience of both speakers. Additionally, repetition helps listeners more easily follow what Obama or Al-Maliki says. Paralleled structures are employed by Obama and Al-Maliki to enhance steadiness, rhythm, and lucidity to the message conveyed. Metonymy, evolving symbolic ideas or images, is manipulated by both speakers to contribute to more profound meanings to common concepts and objects. A simile is only noticed in Obama's address. The comparison between two different things helps him to make his description more forceful or vibrant.

5) In both speeches, although the amounts of abstract nouns are more than those of concrete ones, it seems that the range of English abstract nouns is higher than Arabic ones. Perhaps, this is owing to the functions these nouns perform. Elaborately, the two speakers are trying to touch listeners' feelings using sensitive, abstract, mental expressions reflecting the unity of the themes and the goals in the two speeches.

\section{Conflict of interest statement}

The authors declared that they have no competing interest.

Statement of authorship

The authors have a responsibility for the conception and design of the study. The authors have approved the final article.

Acknowledgments

We are grateful to two anonymous reviewers for their valuable comments on the earlier version of this paper. 
References

Abdul-Raof, H. (2006). Arabic Rhetoric: A Pragmatic Analysis. London: Routledge Taylor \& Francis Group.

Abrams M. H. and Harpham, G. G. (1981). A Glossary of Literary Terms. Wadsworth Publishing.

Al-Ameedi, R. T. K., \& Al-A'ssam, S. A. A. (2018). Retribution in Biblical Texts: A Stylistic Analysis. International Journal of English Linguistics, 8(4), 86-89.

Borowska. A. (2014). Introduction to Paremiology: A Comprehensive Guide to Proverb Studies. Hrisztalina Hrisztova-Gotthardt, Melita Aleksa.

Cappetta, R., Cillo, P., \& Ponti, A. (2006). Convergent designs in fine fashion: An evolutionary model for stylistic innovation. Research Policy, 35(9), 1273-1290. https://doi.org/10.1016/j.respol.2006.02.009

Childs, P., \& Fowler, R. (Eds.). (2006). The Routledge dictionary of literary terms. Routledge.

Chilton, P. A. (2004). Analysing political discourse: Theory and practice. Psychology Press.

Collins Concise English Dictionary (2011). Oxford: Oxford University Press.

Dlugan, A. (2008). "Speech preparation: Add Impact with Rhetorical Devices. Six minutes".

Fahnestock, J. (2011). Rhetorical style: The uses of language in persuasion. Oxford University Press.

Galperin, L. R. (1977). Stylistics (2 ${ }^{\text {nd }}$ ed). Moscow: Higher School.

Harris P. B. (1979). Foundation of Political Science. Sidney: Johannesburg.

Hart, S. L. (1997). Beyond greening: strategies for a sustainable world. Harvard business review, 75(1), 66-77.

Imperatives (2009). www.usingenglish.com/glossary/imperative.html - 20k.

Jabur, A.L. 2007. "Linguistic Aesthetics in English and Arabic". Unpublished M.A thesis. Baghdad: University of Baghdad.

Leech, G. (1981). Semantics: The study of Meaning ( $2^{\text {nd }}$ ed.). Harmondsworth: Penguin.

Leech, G. N., \& Short, M. (2007). Style in fiction: A linguistic introduction to English fictional prose (No. 13). Pearson Education.

Mugair, S. K. (2014). A Stylistic Analysis of "I Have a Dream". International Journal of English and Education, 9(1), 70-77.

Obama, Barack. Obama's Inaugural Address (January 20, 2009). http://obamaspeeches.com/P-Obama-InauguralSpeech-inauguration.htm.

Raffique, S. and Saddique, G. (2014). "Stylistic Analysis of the Poem 'the Onset' by Robert Frost". MA Paper, University of Lahore.

Rohler, L. E., \& Cook, R. (Eds.). (2001). Great speeches for criticism and analysis. Alistair Press.

Sheveleva, A. (2012). Lingo-Rhetorical and Socio-Pragmatic Peculiarities in Political Speeches by Barack Obama. Intercultural Communication Studies, 21(3).

Simpson, P. (2004). Stylistics: A resource book for students. Psychology Press.

Staugaitè, I. (2014). Linguistic realization of rhetorical strategies in Barack Obama and Dalia Grybauskaitè's political speeches (Master's thesis).

Wagner, P., Trouvain, J., \& Zimmerer, F. (2015). In defense of stylistic diversity in speech research. Journal of Phonetics, 48, 1-12. https://doi.org/10.1016/j.wocn.2014.11.001

الهاشمي، احمد. (1 • • ب). جو الهر البلاغة في الدعانسي والبيان و البدبع. بيروت: دار إحياء التر اث العربي.

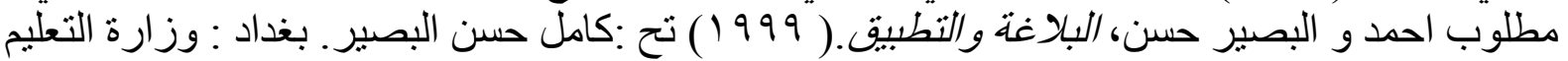

العالي و البحث: العلمي.

Hassan, M. M., \& Hussein, A. L. (2021). Stylistic hallmarks of Obama's (2009) and Al-Maliki's (2006) inaugural addresses. International Journal of Linguistics, Literature and Culture, 7(2), 57-69.

https://doi.org/10.21744/ijllc.v7n2.1142 